\title{
Orędzie prezydenckie w komunikacji publicznej - konwencja i/lub oryginalność a kontekst polityczny
}

Komunikacja publiczna wykorzystuje wiele narzędzi kontaktu wykształconych na przestrzeni wieków: przemówienia, publicystykę polityczną, debaty itp. Orędzia prezydenckie należą do gatunków zrytualizowanych, mających ustalony wzorzec; mieszczą się wśród gatunków związanych z działalnością państwa, tzw. gatunków etatystycznych (Kita 2002, s. 65). Ich układ nadawczo-odbiorczy instytucja/polityk-społeczeństwo ma charakter oficjalny (Kita 2002, s. 66).

Orędzia stanowią część ceremonii objęcia urzędu przez nowego lub powtórnie wybranego prezydenta ${ }^{1}$. Są kraje, w których prezydentura ma długą tradycję, np. w USA jest to już ponad 200 lat: „Od początku istnienia prezydentury w Stanach Zjednoczonych mowa inauguracyjna jest integralną częścią ceremonii zaprzysiężenia prezydenta. Podobieństwo formy przemówień inauguracyjnych spowodowało, iż uznano je za odrębny gatunek retoryki prezydenckiej” (Bulanda 2005, s. 106).

Sięgając do klasyfikacji mów wyróżnionych przez historyków retoryki, przypomnijmy trzy rodzaje wymowy: wymowa sądowa, wymowa doradcza, wymowa pokazowa (Ziomek 1990, s. 61). Według M. Korolki mowy polityczne mieściłyby się w rodzaju doradczym (genus deliberativum): „W dawnym języku polskim istniało z retoryki rodem pojęcie »deliberować« jako odpowiednik właśnie genus deliberativum. W wielu polskich opracowaniach teorii retoryki wymienia się określenie »mowa polityczna« jako odpowiednik »deliberacji«. Wynikało to z faktu, że właśnie rodzaj doradczy ma największe zastosowanie w oratorstwie politycznym, sejmowym czy parlamentarnym" (Korolko 2001, s. 17). Można przyjąć, że orędzie ma cechy mowy doradczej i pokazowej: jest pokazem kunsztu mówcy, zarazem zachęca do czegoś lub od czegoś powstrzymuje.

\footnotetext{
${ }^{1} \mathrm{~W}$ tym tekście będą poddane analizie tylko orędzia inauguracyjne.
} 
Analiza leksykograficzna pokazuje charakterystyczną ewolucję znaczeniową wyrazu orędzie. Stownik języka polskiego S.B. Lindego notuje „1. * Orędzie, *Orendzie 'instrumentum, interes, sprawa'; 2. 'poselstwo, rzecz poselstwa, rozkazu oznajmienie': Od anioła styszat to orendzie. Auszp.97; Przystapiwszy k niej aniol, przepowiedziat jej orędzie niebieskie. Żyw.Jez.B 6" (Linde (1854-1860), t. III, s. 580). W słowniku warszawskim to znaczenie jest opatrzone znakiem ${ }^{\times}$ (mało używane); pierwsze znaczenie zdefiniowano jako 'uroczyste oświadczenie, oznajmienie’: O. cesarskie (Karłowicz, Kryński, Niedźwiedzki (1900-1927), t. III, s. 826). Stownik języka polskiego pod redakcją W. Doroszewskiego jako pierwsze znaczenie podaje: 'uroczyste oznajmienie, oświadczenie osoby wysoko postawionej, skierowane do ogółu w sprawach wielkiej wagi; odezwa, apel': Orędzie Światowej Rady Pokoju wzywa do zjednoczenia wszystkich organizacji, które pragna odprężenia w stosunkach międzynarodowych. Państwo 2, 1954, s. 303 (Doroszewski W. (red.) (1958-1969), t. V, s. 1079). Najbliższa współczesnemu rozumieniu jest definicja zawarta w Innym słowniku języka polskiego pod redakcją M. Bańki: 'oficjalne oświadczenie głowy państwa lub innej wysoko postawionej osobistości, skierowane do narodu w ważnych sprawach' (Bańko (red.) 2000, t. I, s. 1180).

Ostatnia z definicji określa charakter sytuacji (oficjalność) i sprawę, co pośrednio odsyła do wykładników językowych, których wymaga ceremonialna mowa. Te działania komunikacyjne wpisują się w rytuał, który „stanowi dobrowolne wykonanie odpowiednio uwzorowanego zachowania w celu symbolicznego oddziaływania na życie poważne lub uczestnictwa w nim" (Rothenbuhler 2003, s. 45). Komunikację tę można też określić jako „pierwszy akt inscenizacji nowego początku”, podobnie jak exposé premiera (Kampka 2009, s. 101).

\section{Orędzia w II RP}

W polskich warunkach politycznych po odzyskaniu niepodległości w 1918 roku tworzono podstawy kultury politycznej, odwoływano się do zachowań symbolicznych stosowanych w państwach demokratycznych o długiej tradycji. Prezydent był wybierany przez Zgromadzenie Narodowe i składał przed nim przysięgę; po kilku dniach wygłaszał orędzie (Rataj 1965, s. 133, 369)22. Gatunek tekstu

${ }^{2}$ Uprawnienia prezydenta określała Konstytucja z 17 marca 1921 roku; następnie nowela sierpniowa z 2 sierpnia 1926 roku. Konstytucja zwana kwietniową została uchwalona 23 kwietnia 1935 roku. Konstytucja ta bardzo rozszerzała uprawnienia prezydenta RP (por. Tomicki (red.) 1982, s. 92-93, 105-106, 112-113).

W tej części artykułu zostaną zanalizowane mowy prezydentów: Stanisława Wojciechowskiego i Ignacego Mościckiego. 
wpisywał się w kontekst polityczny, który określał temat mowy, czyli sprawę, audytorium, a także podmiot retoryczny ${ }^{3}$.

Orędzie prezydenta Stanisława Wojciechowskiego z 20 grudnia 1922 roku (Wojciechowski 1995, s. 285) jest zwięzłe, składa się z czterech akapitów, a w każdym z nich jest poruszony inny temat. Rozpoczyna się podkreśleniem patetycznego charakteru wydarzenia: „Polacy, Bogu Wszechmogącemu i Tobie, Narodzie Polski, ślubowałem ustawy konstytucyjnej przestrzegać i bronić, dobru powszechnemu wiernie służyć". Mówca odnosi się do śmierci swego poprzednika, Gabriela Narutowicza, który „poległ z ręki, opętanej szałem nienawiści”. W dalszej części wymienia przymioty Rzeczypospolitej i cnoty obywateli: pracę, godność, jedność, miłość, prawo. Patos wypowiedzi jest podkreślony odwołaniem do myśli z pism A. Mickiewicza: „O ile polepszycie dusze wasze, o tyle polepszycie prawa wasze" ${ }^{4}$ i wyliczeniem cnót koniecznych do budowy jednolitego państwa, składającego się z dzielnic z ich odmiennościami odziedziczonymi po zaborach, a mianowicie: braterskiego współdziałania, silnego i trwałego rządu, budżetu, podatków. W części końcowej podmiot retoryczny wzywa do „zgody w sprawach dobra powszechnego", „uzdrowienia życia gospodarczego i wychowania obywateli godnych imienia polskiego".

Adresatem wystąpienia jest Naród Polski, Polacy, Obywatele, a na świadka przywołano Boga Wszechmogącego. Mówca oddziałuje na odbiorcę dzięki formom o funkcji impresywnej (1 os. 1. mnogiej i 2 os. 1. mnogiej): „abyśmy zdołali usunąć [...], godnie wykonać [...], zbudować niepodzielną Rzeczpospolitą; wszyscy miejmy w pamięci; ślubujmy dawać [...] wyraz; skłaniajcie się do zgody [...]". Aksjologii służą wyrazy nazywające wartości: zgoda, zgodny wysiłek, cnoty i praca, niepodzielność kraju, miłość, prawo. Znak wartości otrzymują jednostki neutralne, jak: rząd i budżet, podatki, które w danym kontekście są wartościujące. Posłużenie się słowami Adama Mickiewicza nawiązuje do tradycji romantycznej ${ }^{5}$.

${ }^{3}$ Por. (Gill, Whedbee 2001, s. 182-213). Według przywołanych autorów podmiot retoryczny jest wytworzony przez wypowiedź retoryczną (Gill, Whedbee 2001, s. 192). To rozróżnienie na retora i podmiot retoryczny znajduje analogię w strategii kreowania ról nadawcy, o którym pisze R. Przybylska: „Nadawca w wystąpieniu politycznym zazwyczaj nie reprezentuje tylko samego siebie, ani nawet — przede wszystkim - swojej partii lub swego programu politycznego, lecz w określonym zdarzeniu komunikacyjnym skłania się do tego, by przyjmować różne role społeczne, nakładać »maski«, które czynią z niego określonego aktora sceny politycznej” (Przybylska 2008, s. 280). Autorka wyróżnia pięć różnych ról na podstawie obserwacji form życia politycznego w Polsce. Koncepcję roli wykorzystuję w niniejszej analizie orędzi.

${ }^{4}$ Pełny cytat brzmi: „O ile powiększycie i polepszycie duszę waszą, o tyle polepszycie prawa wasze i powiększycie granice wasze" — zob. Księgi narodu i pielgrzymstwa polskiego, XX, s. 81, https://books.google.pl/books (dostęp: 26 stycznia 2014).

${ }^{5}$ Odwoływanie się do Mickiewicza jako patrona walki o niepodległość jest znane z pism Józefa Piłsudskiego (por. Dawidziak-Kładoczna 2004, s. 70-71). 
Składnia przemówienia jest podporządkowana funkcji impresywnej. Jak stwierdzili autorzy Stylistyki polskiej: „Tak charakterystyczne dla starożytności i staropolszczyzny okresy ustępują w nowoczesnej retoryce zdaniom krótszym, zarówno pojedynczym, jak i złożonym, zazwyczaj oddającym treść jaśniej i przejrzyściej. Zdania krótsze łatwiej docierają do umysłu słuchacza, łatwiej znajdują w jego psychice oddźwięk" (Kurkowska, Skorupka 2001, s. 243).

Prezydent Stanisław Wojciechowski jawi się w świetle przemówienia jako strażnik Konstytucji i sługa dobra powszechnego. Maciej Rataj, ówczesny marszałek sejmu, określił projekt orędzia jako „mistyczny i kooperatystyczny” (Rataj 1965, s. 134). Wpływ na taki kształt mowy miała osobowość prezydenta oraz jego działalność w PPS.

Prezydent Wojciechowski ustąpił z urzędu po zamachu majowym w 1926 roku $^{6}$. Kolejnym prezydentem został Ignacy Mościcki. W swoim orędziu do okoliczności politycznych, które doprowadziły do zmiany władzy, odwołał się dopiero w przedostatnim akapicie: „Niechaj wspomnienie niedawnej rozterki ${ }^{7}$ stanie się podnietą do skupienia żywych sił Narodu w pracy zbiorowej nad wywyższeniem imienia Polski [...]”8. Orędzie z 4 czerwca 1926 roku rozpoczął apostrofą „Do Narodu!”. Patos osiągał przez wielokrotne powtarzanie wyrazów: Naród $(\times 7)$ i Rzeczpospolita $(\times 6)$, przez odwoływanie się do wyznaczników językowych stylu religijnego: „A Ty, Boże, któryś błogosławić raczył wyzwoleniu naszemu [...]”, ,Jak bowiem jeden jest Ojciec nasz w Niebiosach, tak jedna jest Matka Rzeczpospolita Polska [...]”, ,[...] nie mogą kruszyć jedności Rzeczypospolitej różnice dzielnicowe [...]".

Orędzie obfituje w wyznaczniki impresywności, a mianowicie konstrukcje dyrektywne, stosowanie czasowników powinnościowych: „wzywam tedy Was [...]; rozkazuję Wam mocą tej potęgi moralnej; Naród [...] wykonać musi; musi utrwalić jedność wewnętrzną i siłę; niech Imię to jaśnieje; niech Naród Polski będzie w pierwszym szeregu narodów budujących przyszłość ludzkości [...]”. Najwięcej form impresywnych zawiera akapit przedostatni, z anaforą wyrażoną

${ }^{6}$ W historiografii oceny przewrotu majowego są różne, przypisuje mu się m.in. zanik rządów demokratycznych. Społeczeństwo z kolei przyjęło go entuzjastycznie, o czym świadczy zapis w Dziennikach Marii Dąbrowskiej: „Wpośród tych moich planów - stała się w Warszawie rzecz przeraźliwa i wspaniała zarazem, jakby rozdział z historii greckiej. Rewolucja wojskowa o ideał moralny. Dokonał jej Piłsudski, za którym stanęło całe wojsko, cała ulica, cały dół społeczeństwa. Przez trzy dni Warszawa była widownią tragicznej walki nielicznych wojsk rządowych z wojskami Piłsudskiego [...]. Wojciechowski i rząd Witosa zostały zmiecione" (Dąbrowska 1988, s. 179-180).

7 Słowo rozterka, notowane też jako rozterk, zostało użyte przez Mościckiego w znaczeniu dziewiętnastowiecznym: 'niezgoda, niesnaski, rozdwojenie, rozdarcie, poróżnienie, waśń, nieporozumienie' (Karłowicz, Kryński, Niedźwiedzki 1900-1927, t. V, s. 712); por. też Rozterk 'rozłam, zwada, niezgoda, spór gwałtowny', XV-XIX, „Mieliśmy wczoraj dosyć rozterku i zwady, tak w czasie polowania, jako i biesiady” (Mickiewicz 1834), „ówczesny rozterk w Koronie zasłonił to oczom ludzkim" (Szajnocha 1855 - Bańkowski 2014, s. 141-142).

${ }^{8}$ http://laurahuta.blogspot.com/2008/06/oredzie-do-narodu-prezydenta.html (dostęp: 26 stycznia 2014). 
partykułą niechaj. Struktury te podkreślają przynależność do danej społeczności i wypływające stąd obowiązki i przywileje (Małyska 2003, s. 128). Stylistycznie są nacechowane konstrukcje z szykiem przestawnym: „Obowiązek ten wspólnego ze mną działania Narodu wymaga”; „Nie może łamać Narodu prywata”.

Słowa-klucze, podobnie jak w orędziu Stanisława Wojciechowskiego, to: jedność wewnętrzna i siła, wielkość i prawość Ojczyzny, szlachetność i moc, zgodna współpraca ludów, dobro powszechne i cnota.

W obu orędziach występuje wspólny motyw - odwołanie do czasów niewoli, których złe skutki należy przezwyciężyć w odrodzonym państwie: „Proszę Boga Wszechmogącego i Ciebie, Narodzie Polski, abyśmy zdołali usunąć z uczuć i czynów naszych zło długoletniej niewoli i wojny [...]” (Wojciechowski); „Naród, wydźwignięty z niewoli, wykonać musi olbrzymi wysiłek moralnego i materialnego odrodzenia”; „Rzeczpospolita po wiekowym rozdarciu połączona, musi utrwalić jedność wewnętrzną i siłę" (Mościcki).

Należy zauważyć, że brak w orędziu I. Mościckiego takich konkretów, jak praca, budżet, podatki, które mogą budować siłę Rzeczpospolitej. Obfituje ono w wezwania do czynów i wyliczenie cnót, mających charakter abstrakcyjny. Można mówić o przewadze funkcji perswazyjnej nad informacyjną. Podmiot retoryczny podkreśla godność urzędu prezydenta, stosując archaiczne konstrukcje składniowe: ,powołany wyborem Zgromadzenia Narodowego na stanowisko Prezydenta Rzeczypospolitej [...]"9; „,rozkazuję Wam mocą tej potęgi moralnej, jaka w Urzędzie obranego przez Wolny Naród Prezydenta jest zawarta [...]".

W świetle przytoczonych danych można przyjąć, że prezydent kreuje się na ojca narodu, który „wzywa i rozkazuje”.

Obydwaj mówcy nawiązują do kontekstu politycznego, w którym obejmują urząd, ale Ignacy Mościcki nie nazywa wprost wydarzeń, które zaszły w maju 1926 roku. W tekstach podobne jest odwołanie do sacrum; charakterystyczne są zespolenia szeregowe o funkcji pozytywnej, np. mitość i praca, dostojność i moc, jedność wewnętrzna i siła.

\section{Orędzia w III RP}

Po 1989 roku nastąpił powrót do ceremonii z II RP: wybór prezydenta, zaprzysiężenie przed Zgromadzeniem Narodowym oraz wygłoszenie orędzia ${ }^{10}$. Zmiana warunków komunikacyjnych sprawiła, że implikowane audytorium nie

9 Struktura powołany czym jest notowana w Stowniku polszczyzny XVI wieku (2001, s. 232): „Także y Bernat Swiety powiada/Boiaźnia powołani/ale miłością usprawiedliwieni bywamy”. WujJud 96.

${ }^{10}$ W tej części tekstu zanalizuję orędzia prezydentów: Lecha Kaczyńskiego i Bronisława Komorowskiego. 
jest tożsame z tym, które jest w bezpośrednim kontakcie z nadawcą - dociera ono przez radio, telewizję, internet do wielu odbiorców.

Mówca (Lech Kaczyński) bezpośrednio zwraca się do obecnych w rozbudowanej apostrofie: „Szanowny Panie Prezydencie! Panowie Marszałkowie Sejmu i Senatu! Wysokie Zgromadzenie! Eminencjo Księże Prymasie! Ekscelencje Księża Arcybiskupi i Biskupi! Dostojni Przedstawiciele Innych Wyznań! Dostojni Goście!”. Kilkakrotnie w czasie wygłaszania mowy przerywa ją apostrofami: „Panowie Marszałkowie! Wysokie Zgromadzenie! Panie i Panowie Senatorowie i Posłowie! Panie i Panowie Posłowie! Panie i Panowie Senatorowie!", co służy wzmocnieniu funkcji fatycznej i perswazyjnej ${ }^{11}$. Odbiorcami mowy są Polacy w kolejności wymieniania: jednostki i rodziny, miasto i wieś, regiony, konsumenci, pracownicy i pracodawcy, Rodacy żyjący poza granicami kraju.

Z kolei w orędziu prezydenta Bronisława Komorowskiego nawiązaniu kontaktu z odbiorcami służą formuły: „święto, w którym ma udział [...] każda Polka, każdy Polak"; ,zwracam się [...] do moich rodaków”; kolejni adresaci: my; wszyscy; naród; my, polscy obywatele; my, społeczeństwo, a także „wielka polonijna rodzina". Najczęściej spośród wymienionych używany jest leksem obywatel w znaczeniu prawnym 'członek społeczeństwa danego państwa mający określone uprawnienia i obowiązki zastrzeżone przez prawo i konstytucję' (Dubisz (red.) 2003 , t. 3, s. 64).

W orędziu prezydenta Lecha Kaczyńskiego sprawą, wokół której ogniskuje się mowa, jest zmiana ${ }^{12}$. Począwszy od pierwszego akapitu, wezwanie do zmiany jest przedstawiane wielokrotnie: „oczekiwanie wielkiej, pozytywnej zmiany”; „musi nastąpić głęboka zmiana”; „moralna zmiana”; „nie wolno przeciwstawiać jej [tradycji - E.S.] koniecznym zmianom”; „oczekiwanie na wielką pozytywną zmianę”; „nakłaniać rządzących do wprowadzenia koniecznych zmian”. W zakończeniu to słowo zostało użyte kilkakrotnie: „Mamy zmienić Polskę, ale bez Was jej nie zmienimy. A zmienić ją koniecznie trzeba". W mowie występują też bliskoznaczniki kontekstowe: proces przemian, przebudowa, przemiana, napra$w a^{13}$. Realizacja zmian ma doprowadzić, zdaniem prezydenta Lecha Kaczyńskiego, „do uwieńczenia budowy tego, co nazywamy IV Rzecząpospolitą" ${ }^{14}$.

11 http://www.prezydent.pl/archiwum/archiwum-aktualnosci/rok-2005/art,151,427,urocz... (dostęp: 23 lutego 2014).

12 Ukierunkowanie na przyszłość, naprawa życia publicznego, odnowa to częsty topos języka polityki, występujący m.in. w exposé premierów (por. Kampka 2009, s. 101-107).

13 Naprawa była też motywem kampanii wyborczej PiS w 2007 roku (por. Czyżyk-Cyzio 2011, s. 47).

14 Prezydent powinien zrezygnować z roli rzecznika własnej partii z chwilą objęcia urzędu. Jednak nie zawsze ta zasada jest przestrzegana. Wydaje się, że używanie przez prezydenta Lecha Kaczyńskiego słowa zmiana wpisuje się w retorykę zwolenników IV RP, którzy temu wyrazowi przypisali odpowiedni znak wartościujący, co tak skomentował Michał Głowiński: „W języku Prawa i Sprawiedliwości użycie tego słowa zostało w sposób charakterystyczny zacieśnione: »zmiana« (w liczbie pojedynczej lub mnogiej) stosuje się tylko do tego, co ta partia robi bądź robić zamierza, 
Konieczność wprowadzenia zmian pociąga za sobą wyliczanie zjawisk negatywnych, a są to: przestępczość korupcyjna, fatalny stan dróg, społeczne dystanse, degeneracja instytucji rynkowych, degeneracja aparatu państwowego, bezrobocie, kryzys służby zdrowia. Konsekwencją konieczności zmian jest rola, jaką przyjmuje podmiot retoryczny, wyrażana następująco: „zadaniem, przed którym stoję ja [...] jest sprostać temu oczekiwaniu, nie zawieść nadziei, podjąć budowę nowego kształtu naszego życia”; „Ta naprawa, Wysokie Zgromadzenie, to zadanie konkretne”; „Jako Prezydent Rzeczypospolitej Polskiej uczynię wszystko, wszystko, co możliwe, by oczekiwanie na wielką pozytywną zmianę nie zostało zawiedzione”; „Będę wykorzystywał wszystkie uprawnienia [...] by nakłaniać rządzących do wprowadzenia koniecznych zmian [...]”; „Podejmę wysiłki zmierzające do umocnienia społecznych podstaw całego procesu przemian [...]"; „Dziś moim zadaniem jest uczynienie wszystkiego, by zapewnić bezpieczeństwo [...]”; „Będę podejmował wysiłki [...]”. Zwraca tu uwagę dominacja 1. osoby 1. pojedynczej — podmiot retoryczny kreuje się na samotnego przywódcę, który steruje zmianami, przewodzi im; co charakterystyczne, rzadko w przemówieniu jest deklarowana współpraca z innymi organami państwa, np. „Polityka zagraniczna, którą chcę wraz z rządem prowadzić, musi być energiczna [...]”.

Budowa nowego porządku publicznego, walka z patologiami pociąga za sobą nakłonienie do działań, do wykonywania zadań, stąd duża liczba konstrukcji impresywnych, oddziałujących na odbiorcę. Dyrektywy przyjmują różną formę językową: stosowanie bezokoliczników, zdań powinnościowych z trzeba, potrzeba, powinno + bezokolicznik, musieć + bezokolicznik, np.: „trzeba jasno powiedzieć, zbyt mało było solidarności”; „musi nastąpić głęboka zmiana”; „obowiązki państwa [...] muszą być wykonywane”; „muszą być systematycznie niwelowane”; „Państwo [...] musi być oczyszczone i przebudowane”; „nasze państwo [...] powinno wejść na tę droge”; ,trzeba podjąć trud”; „stosunki ze Stanami Zjednoczonymi trzeba [...] zacieśniać”; „musimy podjąć bardziej dalekosiężne działania”; „nową jakość trzeba nadać [...]”; „sojusz z Ukrainą powinien nabrać bardziej konkretnych kształtów”; ,żywą treść trzeba nadać porozumieniu wyszehradzkiemu”; ,istnieje wielka potrzeba daleko idącej zmiany”.

W przemówieniu Bronisława Komorowskiego wizerunek prezydenta określają konstrukcje z czasownikami: wspieraćc ${ }^{15}$, sprzyjać, patronować, np. „będę starał się tak sprawować urząd prezydencki, by zyskać ich zrozumienie i uzna-

stosuje się do starań o wprowadzenie nowego porządku, który ma zyskać najwyższą aprobatę, ma przekształcić kraj i spowodować, by zapanowało w nim bezwzględne dobro. Słowo to funkcjonuje tutaj wyłącznie z radykalnie pozytywnym znakiem wartościującym: my chcemy zmian i je w życie wprowadzamy, kto jest przeciw nim czy je kwestionuje, jest przeciw zmianom. Ewentualność, że opozycja również dąży do zmian, ale pojmuje je inaczej, jest wykluczona" (Głowiński 2009, s. 218 219).

15 Czasownik wesprzeć wskazuje na integrowanie ludzi, instytucji wokół jakiejś sprawy, por. 'Jeśli wsparliśmy jakąś osobę, instytucję lub organizację albo jej działalność, to pomogliśmy jej w jakiś sposób, np. finansowo, zbrojnie lub moralnie’ (Bańko (red.) 2000, t. II, s. 986). 
nie”; „będę szukał także innych sposobów wymiany myśli, poglądów”; „chcę [...] debatę i inicjatywy wspierać, chcę im patronować”; „będę służył rządowi wsparciem w tym ważnym zadaniu”; „będę sprzyjał rozpoczętemu procesowi zbliżenia i pojednania polsko-rosyjskiego"; ,[...] parlament i rząd będą miały we mnie sprzymierzeńca”; „będę wspierał modernizację kraju”; „będę umacniał i wspierał więzi łączące nas we współpracy dla rozwoju i pomyślności Polski”.

Podmiot retoryczny jawi się na podstawie tych deklaracji jako strażnik i mediator, podejmujący współpracę z partiami, sprzymierzeniec rządu i obywateli: „Zadaniem prezydenta jest i będzie zabieganie o to, aby nikt z racji urodzenia, stopnia sprawności, wieku, wykształcenia czy miejsca zamieszkania nie był pozbawiony możliwości bycia we wspólnocie i pomocy w trudnej sytuacji”.

$\mathrm{Na}$ przyszłość ukierunkowane są formuły normatywne. Nakłanianiu i wyznaczaniu wspólnych działań służą konstrukcje: 1) stosowanie 1 os. 1. mnogiej czasowników modalnych musieć, potrzebować: „musimy umocnić podstawy do trwałego rozwoju społecznego i gospodarczego”; „musimy inwestować w badania naukowe”; „musimy wspólnym wysiłkiem likwidować bariery utrudniające start życiowy młodych ludzi”; ,potrzebujemy ładu przejawiającego się w rzetelnie działających instytucjach państwa"; 2) zdania powinnościowe z czasownikiem trzeba: „trzeba nam więcej spokoju i zrozumienia”; „nie trzeba mnożyć lęków i zamykać się w sobie”; „trzeba, by w większym stopniu wypełniała ją [przestrzeń życia społecznego - E.S.] obywatelska aktywność".

Cel i temat orędzia (,sprawy wielkiej wagi”) mają wpływ na aktualizowane wartości. W orędziu Lecha Kaczyńskiego pozytywny znak wartości otrzymała zmiana $(\times 9)$ i jej bliskoznaczniki: naprawa, przebudowa, przemiana; w służbie państwu niezbędne są takie wartości, jak: sprawiedliwość, solidarność, uczciwość, służą one dobru Polski, dobru narodu. Wspólny występuje w wyrażeniu dobro wspólne, wspólny dorobek, naród jako wspólnota. Również Bronisław Komorowski odwołuje się do różnych typów wartości pozytywnych: wartości moralnych (moralność spoteczna) oraz do kategorii bliskości (podtyp wartości odczuciowych (Puzynina 1992, s. 157-176)). Środki językowe służące jej wyrażeniu są następujące: zaimek nasz, my; nasz występuje w orędziu ok. 25 razy: „nasze społeczeństwo”, „nasze państwo”, „nasz naród”, „,nasza ojczyzna”, ,nasz kraj”, „model naszej demokracji”, „,nasze polskie interesy”, „nasz region”, „,nasze zobowiązania". Kolejnymi wyrazami z tej klasy, służącymi integrowaniu społeczeństwa, są wspólny/wspólnota; zastosowano je 14 razy, np.: „,wspólnie zdziałać”, „wspólna tragedia”, „wspólny fundament”, „poczucie wspólnoty/narodowej wspólnoty”, „być we wspólnocie”, „wspólna Europa”, „wspólna polityka bezpieczeństwa i obrony”, „wspólny namysł”, „wspólny wysiłek”, „wspólne działania”, „umacniać wspólnotę środkowoeuropejskich interesów”, „dobro wspólne/nasze wspólne dobro" (Sękowska 2011, s. 183).

Te środki słowne służą amplifikacji — uwydatnieniu wagi i znaczenia omawianej sprawy, w opisywanych przypadkach — kondycji kraju. 
Strategicznymi pozycjami w tekście są części początkowe i końcowe, zakończenie decyduje o ostatecznym efekcie perswazji. U prezydenta Kaczyńskiego utrzymane było w stylistyce całego wystąpienia: „Zwracam się do Was, Rodacy, abyście mimo wszystkich zawodów raz jeszcze uwierzyli. Mamy zmienić Polskę, ale bez Was jej nie zmienimy. A zmienić ją koniecznie trzeba”. W orędziu prezydenta Komorowskiego brzmiało następująco: „Wygłoszone dziś deklaracje o współpracy, dialogu i otwartości pozostaną dla mnie niezmiennym drogowskazem. Wierzę w polską drogę, wierzę, że można iść nią odważnie i śmiało do przodu. Wierzę w Polskę. Wierzę w patriotyzm codziennego trudu, codziennej pracy. Co więcej, wierzę w nas, Polaków".

Obydwa zakończenia odzwierciedlają przekonania mówców i wizję przewodzenia państwu, dokumentują różne role przyjmowane przez nich, stąd akcenty położone są na inne aspekty działań.

Warto jeszcze przyjrzeć się wybranym środkom językowym, nadającym przemówieniom walor skuteczności i stosowności. Wyżej zwracano uwagę na konstrukcje perswazyjne i sposoby wartościowania, teraz pora na środki obrazowania. Są to nieliczne i zleksykalizowane metafory; metafora budowy, nota bene, utrwalona w języku polityki - 'tworzenie nowego porządku': „budowa dobrego porządku publicznego”; „budowa IV Rzeczypospolitej”; „państwo musi być oczyszczone i przebudowane”; metafora drogi jako 'sposobu działania': „nasze państwo [...] powinno wejść na tę drogę”; „drogą do tego jest odrzucenie narodowych kompleksów" (orędzie L. Kaczyńskiego).

W mowie B. Komorowskiego wystąpiła duża liczba konstrukcji szeregowych: „spory i walki partyjne”; „rozwój i modernizacja kraju”; „obszary zaangażowania i współodpowiedzialności”; „, duchu otwartości i solidarności”; „przyszłość i jakość życia”; „sprawna i życzliwa administracja”. Nadały one wystąpieniu charakter oficjalny, publicystyczny; wrażenie to było spotęgowane przez wprowadzenie konstrukcji językowych, nazywających procesy gospodarcze i społeczne ostatnich kilku/kilkunastu lat, oraz zleksykalizowanych metafor: „stan spraw publicznych”; „skok edukacyjny”; „mechanizmy demokratyczne”; „solidarnościowe korzenie”; „europejskie zakorzenienie Polski”; „partner unijny”; „sojusznicze zobowiązania”; „filar polskiej polityki zagranicznej”; ,utrzymać w ryzach finanse państwa”; „budowa społeczeństwa obywatelskiego”; „poprawa opieki zdrowotnej”; „godna emerytura”; „cywilizacyjna szansa”; „człowiek Solidarności”. Struktury te osadzają wypowiedź w realiach danego momentu historycznego, a ich nagromadzenie pełni funkcję nakłaniającą.

Konwencja v. oryginalność w odniesieniu do przemówień politycznych, jakimi są analizowane orędzia, nie stanowi cech wyłączających się. Orędzia realizują wzorzec przemówień okolicznościowych, zastosowane środki językowe odpowiadają rytualnemu zachowaniu, a cel wypowiedzi polega na przekonaniu audytorium do prezentowanej wizji państwa i polityki. Określony jest również temat, a raczej pewien krąg tematyczny, do którego mówca się odnosi (por. definicję 
słownikową orędzia). Oryginalność zaś wynika z kontekstu politycznego oraz roli podmiotu retorycznego — to one dyktują wybór aksjologii, konstrukcji dyrektywnych; z kolei warunki historyczne wpływają na kontekst mowy, na autorytety, do których odwołują się politycy. Każdy z analizowanych tekstów prezentuje inne audytorium implikowane, rozumiane jako konstrukt fikcyjny, ,ponieważ zostaje wytworzone w akcie mówienia i istnieje jedynie w symbolicznym świecie tekstu" (Gill, Whedbee 2001, s. 193). Mimo że za każdym razem są to obywatele Polski, to audytorium implikowane jest inne: Naród Polski, obywatele (Wojciechowski), Naród, naród wydźwignięty z niewoli, Obywatele Najjaśniejszej Rzeczypospolitej (Mościcki), Polacy, Rodacy, konsumenci, pracownicy i pracodawcy, Rodacy żyjący poza granicami kraju (Kaczyński), Rodacy, polscy obywatele, wielka polonijna rodzina (Komorowski). Ta kategoria jest uwarunkowana rolą podmiotu retorycznego, wykreowanego w ramach danego tekstu.

Dodałabym do tych czynników również wpływ osobowości polityka i jego rodowodu partyjnego (por. mowy Wojciechowskiego, Kaczyńskiego, Komorowskiego).

Orędzie jest wyspecjalizowanym gatunkiem, charakterystycznym dla komunikacji publicznej. Po przeanalizowaniu mów inauguracyjnych pozostałych prezydentów III RP można by pokusić się o pokazanie podobieństw i różnic między nimi, o zidentyfikowanie pewnych stałych motywów, o określenie wpływu konkretnego momentu historycznego. Te czynniki wpływają również na kształt językowostylistyczny wystąpień.

Język orędzi można też wiązać z danym typem kultury politycznej: zaściankowej (parafialnej), podporządkowanej (poddańczej), uczestnictwa (por. Kamińska-Szmaj 2008, s. 254). Takie ujęcie wykracza poza przyjęty schemat rozważań.

\section{Bibliografia}

Bańko M. (red.) (2000), Inny słownik języka polskiego, Warszawa.

Bańkowski A. (2014), Etymologiczny stownik mowy polskiej, t. 3, cz. I, Częstochowa.

Bulanda A. (2005), Retoryka przemówień inauguracyjnych prezydentów amerykańskich XX wieku, „Forum Artis Rhetoricae”, nr 1-2 (3-4), styczeń-maj, s. 106-125.

Czyżyk-Cyzio A. (2011), Retoryka strachu. O perswazji w kampanii wyborczej z 2007 roku, „Polonica" XXXI, Kraków, s. 37-51.

Dawidziak-Kładoczna M. (2004), ,, Cherlacy z sercem oziębłym”. O języku pism i mów Józefa Pitsudskiego, Łask.

Dąbrowska M. (1988), Dzienniki 1914-1932, wybór, wstęp i przypisy T. Drewnowski, Warszawa.

Doroszewski W. (red.) (1958-1969), Stownik języka polskiego, Warszawa.

Dubisz S. (red.) (2003), Uniwersalny stownik języka polskiego, Warszawa.

Gill A.M., Whedbee K. (2001), Retoryka, [w:] Dyskurs jako struktura i proces, red. T. van Dijk, Warszawa.

Głowiński M. (2009), Nowomowa i ciagi dalsze. Szkice dawne i nowe, Kraków.

http://laurahuta.blogspot.com/2008/06/oredzie-do-narodu-prezydenta.html. 
http://www.prezydent.pk/archiwum/archiwum-aktualnosci/rok-2005/art,151,427,urocz...

Kamińska-Szmaj I. (2008), Język polityki na tle przemian kulturowych, „Język a Kultura” 20, Wroclaw, s. 253-265.

Kampka A. (2009), Perswazja w języku polityki, Warszawa.

Karłowicz J., Kryński A., Niedźwiedzki W. (1900-1927), Słownik języka polskiego (tzw. słownik warszawski), Warszawa.

Kita M. (2002), Państwo jako generator gatunków mowy, „Biuletyn PTJ”, z. LVIII, Kraków, s. 65-74.

Korolko M. (2001), Retoryka i erystyka dla prawników, Warszawa.

Księgi narodu i pielgrzymstwa polskiego, XX, s. 81, https://books.google.pl/books.

Kurkowska H., Skorupka S. (2001), Stylistyka polska. Zarys, Warszawa.

Linde S.B. (1854-1860), Stownik języka polskiego, wyd. II, Lwów.

Małyska A. (2003), Rytuaty sejmowe w latach 1980-1982 i 1991-1993, Lublin.

Przybylska R. (2008), Jak stworzyć typologię wystapień politycznych polityków, „Język a Kultura” 20, Wrocław, s. 279-285.

Puzynina J. (1992), Język wartości, Warszawa.

Rataj M. (1965), Pamiętniki, do druku przygotował J. Dębski, Warszawa.

Rothenbuhler E.W. (2003), Komunikacja rytualna. Od rozmowy codziennej do ceremonii medialnej, przeł. i red. J. Barański, Kraków.

Sękowska E. (2011), Orędzie prezydenta Bronisława Komorowskiego - rytuat czy innowacja?, [w:] Polskie dźwięki, polskie słowa, polska gramatyka, red. B. Pędzich, D. Zdunkiewicz-Jedynak, Warszawa, s. 181-186.

Stownik polszczyzny XVI wieku (2001), t. XXIX, red. K. Wilczewska, L. Woronczakowa, Warszawa.

Tomicki J. (red.) (1982), Polska odrodzona 1918-1939. Państwo - spoleczeństwo - kultura, Warszawa.

Wojciechowski S. (1995), Wspomnienia, orędzia, artykuty, wstęp, wybór fragmentów wspomnień, przemówień, orędzi, relacji i artykułów: M. Groń-Drozdowska, M.M. Drozdowski, Warszawa.

Ziomek J. (1990), Retoryka opisowa, Wrocław.

\section{The proclamations of presidents in public communication — ritual and/or novelty and the political context}

\section{Summary}

The article analyses proclamations pronounced by four Polish presidents: S. Wojciechowski, I. Mościcki, L. Kaczyński and B. Komorowski. The president's inaugural proclamation is a ritualised genre directed at the nation, concerning matters of high importance. Its structure depends on the political context which defines the topic, the audience and the role of the rhetoric subject. The proclamations contain axiological vocabulary, defined by the country's historical situation, as well as pathetic constructions. Also, in this genre the impressive function predominates. The linguistic means of persuasion are independent of the historical period, nonetheless, its intensity differs. The construction of the implied receiver differs from text to text, which is a result of the role taken by the speaker.

Keywords: proclamation, genre, sender, audience, political context 